\title{
Ergocycle Test for The Disabled Children
}

\author{
Sri Ayu Wahyuti \\ Master Program in Sport Sciences \\ Universitas Negeri Yogyakarta \\ Yogyakarta, Indonesia \\ sriayuwahyuti04@gmail.com
}

\author{
Siswantoyo \\ Faculty of Sport Sciences \\ Universitas Negeri Yogyakarta \\ Yogyakarta, Indonesia \\ spcl_fikuny@yahoo.com
}

\begin{abstract}
- the integration of physical education, sports, and health are part of the education system designed for the disabled children. The physical fitness in these children is considered very important in order to perform the physical activity. Consequently, is necessary to develop an instrument with the aim to evaluate the physical fitness status of the disabled child. The improvement of the sports facilities and infrastructure is very important in order to support the physical activity of special needs children. The survey method was used in this research combined with a qualitative descriptive method. Random sampling technique was used in five physical exercise and open-ended question questionnaires were used with the objective to obtain information. The result of the study in one school in Yogyakarta, Indonesia, has been revealed that the facilities and infrastructure necessaries in the implementation of teaching and learning activities are limited, especially, the physical fitness equipment for disabled children. Based on these results, the authors suggest a modification of an Ergocycle product by paddling using hands. This Ergocycle test, cheaply and durable has been designed in a with the aim to facilitate the use of children with special needs for low impedance
\end{abstract}

\section{Keywords—ergocycle, physical fitness, disabled}

\section{INTRODUCTION}

Physical education is a process focused on developing physical fitness and the ability to perform daily physical activities. The sports activity encourage the survival, develop psychomotor, affective and cognitive skills, and, as a result, improve physical fitness. Children with physical disabilities need to practice physical activity with the aim to improve body functions. Physical activity is a component required for the health and is very useful for a physically disabled child because they have a greater need for motion. Experts have been revealed that physical activity is essential to develop better health and life for all children and adolescents with physical disabilities [1]. Although the limited facilities and infrastructure for people with disabilities constitute a barrier to the practice of physical exercise.

The results of the study [14] have been shown that sports barriers are largely due to a non-supportive environment for physically disabled and inadequate facilitators impeding the intention to participate in sports. The study has been revealed the maximum aerobic capacity research (VO2max) for industrial sector workers using ergocycle tests. The tests were carried out in the laboratory, between 8 am and $2 \mathrm{pm}$. The average temperature was $20.5 \mathrm{C}$, relative humidity $41 \%$ and air pressure $857 \mathrm{hPa}$. The results have been shown that there is a relationship between the age, BMI, hours of practice and smoking. Although there is no relationship between VO2 max and height, weight, nature of work and work schedule (2).

Physical abnormalities can be defined as abnormalities on organs functions. Somantri [3] have been stated that dullness is considered a subtle term for people who have a physical deformity with loss of several limbs such as legs, hands and body shape. Motor function disorder is an example of physical abnormality Nandiya [4] have been revealed that the motor dysfunction of the body or " tuna daksa" is a disorder that affects one or more limbs producing difficult movement and inability to perform normal daily activities. The cause of motor dysfunction can be acquired or congenital. The affected individuals can experience physical abnormalities considered motor function disorders.

Physical fitness is related to the ability to perform a physical activity. There is a proportional relation between these elements: the increment of the physical activity will increase the physical fitness or otherwise (Caspersen, Powell, \& Christenson, 1985) [5]. Physical activity is very important for the health and wellbeing of children and adolescents irrespective of the presence or absence of disability [1]. Physical activity programs after curricular hours are considered important. They develop a good integration of social relations and improvement of the psychological aspects and well-being of children and adolescents regardless of the presence or absence of disability [1]. Physical activity programs outside of school are important to develop social and psychological relationships and positive physical skills in children, adolescents and physically disabled persons [6]. [2] It is influenced by environmental factors (eg cost, accessibility, built environment, information, and social support) and personal factors (eg age, self-efficacy, depression, and mental health).

\section{METHODS}

This study is a qualitative descriptive research. The survey method was used to collect valid data or information. We used as subjects 5 sports teachers who taught in extraordinary schools. Data collection techniques were conducted using an open-ended question consisting of 13 questions. The questionnaire consisted of 9 multiple choices and 4 description questions, on multiple choice questions allowing free answer questions with the aim of obtaining accurate information. 


\section{RESULTS AND DISCUSSION}

The physical education is an important process that helps to improve and develop the physical, psychomotor, cognitive and affective aspects of students. The main objective of this process is to implement the physical activity for the improvement of the physical, intellectual, social and emotional ability of the individuals. Physical fitness is useful as a builder of muscular strength and endurance. Other important effects of the fitness are to increase aerobic endurance and flexibility, burns calories, reduces stress and increases the passion. The physical fitness is necessary to be included as part of the daily activities. The practice of sports in the schools is one of the physical activities that can increase the movement of children with disabilities. Physical education and adaptive health for children with special needs can promote the growth and development of physical fitness, movement, social, and intellectual skills. It can be evaluated throughout physical fitness tests. the researcher, based on the preliminary survey results and problem analysis, analyzed the importance of the existence of a fitness equipment for underdogs identifying the level of fitness as a gold standard.

\section{CONCLUSION}

Provision of ergocycle equipment is very important for people with disabilities. the physical activities will improve physical fitness in patients with disability. as a result, they will be able to perform independently daily activities. This research will provide advice to sports policy manufacturers to improve different facilities with the aim to increase sports participation, especially patients with physical disabilities.

\section{REFERENCES}

[1] L. White, Z. Volfson, G. Faulkner, and K. Arbour-Nicitopoulos, "Reliability and Validity of Physical Activity Instruments Used in Children and Youth With Physical Disabilities: A Systematic Review", Journal of Human Kinetics Pediatric Exercise Science, 2016, 28, 240263

[2] H. Daneshmandi, A. R. Fard \& A. Choobineh, "Estimation of Aerobic Capacity and Determination of Its Associated Factors Among Male Workers of Industrial Sector of Iran, International Journal of Occupational Safety and Ergonomics, 2013, 19:4, 667-673

[3] S. Sujihati, "Psikologi Anak Luar Biasa", PT. efika Aditama, Bandung, 2006.

[4] N. Abdullah, "Engenal Anak Berkebutuhan Khusus" Magistra No. 86 Th. XXV (2013), ISSN 0215-9511

[5] K. Hesseberg, H. Bentzen, A. Hylen Ranhoff, K. Engedal, and A. Bergland, "Physical Fitness in Older People with Mild Cognitive Impairment and Dementia", Journal of Aging and Physical Activity, 2016, 24, 92-100.

[6] K. P. Arbour-Nicitopoulos, A. C. McPherson, F. V. Wright, G. E. Faulkner, V. Grassmann and K. Orr, "A Scoping Review of Inclusive Out-of-School Time Physical Activity Programs for Children and Youth With Physical Disabilities", Journal of Adapted Physical Activity Quarterly, 2018, 35, 111-138.

[14] E. A. Jaarsma, an H.B. Geertzen. R. de Jong, P. U. Dijkstra and R. D. Barriers \& Facilitators of sports in Dutch Paralympic Athletes: An explorative study", Scandinavian Journal of Medicine and Science in Sports, 2013, doi:10.1111/sms.12071

[7] R. A. Sorayya, Huldani And Asnawati, "Perbedaan Tekanan Darah Sesudah Tes Ergocycle Pada Mahasiswi Fakultas Kedokteran Unlam Yang Menstruasi Dan Tidak Menstruasi”, Berkala Kedokteran, 2014, Vol.10, No $1: 17-23$ 